\title{
A Brief Discussion on the Design of Activity View of High School English Learning under Task- based Teaching Method
}

\author{
Aiping Zhang \\ School of Foreign Language, China West Normal University, Nanchong, Sichuan, China
}

\begin{abstract}
The disadvantages of traditional teaching methods, such as the direct method, the grammar translation method, are becoming more and more obvious. The task-based teaching method, which pays more attention to students' subjective initiative, independent learning and cooperative inquiry, is becoming more and more popular. It shows the student-centered teaching concept and coincides with the guiding ideology of the new curriculum reform. Under the new curriculum reform, it advocates activity view of English learning for the development of discipline core literacy. Therefore, it is particularly important to integrate the task-based language teaching (TBLT) and activity view of English learning to design high school English teaching.
\end{abstract}

Keywords: TBLT; activity view of English learning; high school English

\section{Introduction}

The way of English teaching in senior high school has experienced the change of the three ages of pre-methodology, methodology and post-methodology. It is rare to use a single teaching method, but more to adjust and integrate the teaching methods according to the actual situation of students and the current development. TBLT is a foreign language teaching method which developed gradually from 1980s and widely accepted by linguists and foreign language teaching practitioners. It aims to stimulate students' interest in learning language, and develop their interpersonal thinking, decisionmaking and strain capacity through completing various tasks and activities. TBLT is not static. Rod Ellis (2009) emphasizes that there is no unique TBLT, but there are different modes of TBLT, which can be combined with other methods. This also shows that TBLT has great potential for development and flexibility, and keeps pace with the times. One of the changes of the current new curriculum reform (2017 version) is that it no longer refers to specific learning activities such as task-based activities, but advocates activity view of English learning. Under the background of the view of learning activities, how to treat task-based learning is a problem we should discuss seriously.

\section{The Connotation of Task-based Teaching Method}

The English Curriculum Standards for Senior Middle Schools in 2003 (experimental draft) points out that TBLT should be tried in English teaching. The core of TBLT is task. As for what is task, different scholars have different definitions. Ellis (2009) believed that a task is an activity that requires learners to use language to achieve a certain purpose

Copyright (C) 2020 by author(s) and Frontier Scientific Research Publishing Inc.

This work is licensed under the Creative Commons Attribution International License (CC BY 4.0).

http://creativecommons.org/licenses/by/4.0/ 
and emphasizes the expression of meaning in the process of the activity. Clark, Scarino and Brownell (1994) gave a more comprehensive definition of a task. They thought that a task consists of four elements: (1) purpose: the task must be purposeful; (2) context: task design should be based on a certain context; (3) process: the task process should cultivate students' ability of generalization, problem solving, communicative competence, etc.; (4) product: the quality assessment of task completion is based on the result of task. The characteristic of TBLT is to provide students with opportunities to put them in real scenes, because real scenes can enable students to experience and understand language without any constraints in a relaxed environment (Yu Lijuan, 2016).

\section{The Connotation of English Learning Activity View}

The Curriculum Standard (2017 Edition) proposes the curriculum content which consists of six elements: subject situation, discourse type, language knowledge, cultural knowledge, language skills and learning strategies, as well as activity view of English learning pointing to the development of the discipline core literacy. The activity view of English learning refers to a series of English learning activities which embody the characteristics of comprehensiveness, relevance and practicality through learning comprehension, application practice, transfer innovation under the guidance of thematic meaning, so that students can promote their own language learning, cultural connotation understanding, multiple thinking development, value orientation judgment and use of learning strategies in the process of analyzing and solving problems based on existing knowledge and relying on different types of discourse. This process is not only the process of integration and development of language knowledge and language skills, but also the process of increasing cultural awareness, improving the quality of thinking and improving learning ability (Ministry of Education, 2018).

\section{Design of English Learning Activity View under Task-based Teaching Method}

4.1 Teaching design of TBLT

\begin{tabular}{|c|c|}
\hline $\begin{array}{l}\text { Teaching } \\
\text { procedures }\end{array}$ & Activity design \\
\hline Pre-task & $\begin{array}{l}\text { 1.Clarify the purpose of the task; } \\
\text { 2.Set up tasks close to students' real life and determine the difficulty according to } \\
\text { the learning situation; } \\
\text { 3.Introduce task background or themes; } \\
\text { 4.Students prepare themselves, perceiving the main idea, related knowledge, } \\
\text { vocabulary, sentence patterns and grammar. }\end{array}$ \\
\hline While-task & $\begin{array}{l}\text { 1.Give students the opportunity to express language and let students create their } \\
\qquad \text { own language environment; } \\
\text { 2.Students complete a series of classroom tasks under the guidance of teachers -- } \\
\text { first, understand of the main idea; second, complete the corresponding detailed } \\
\text { task; then, students will form a task report on the completion of the task and } \\
\text { present it to the class or teachers. }\end{array}$ \\
\hline Post-task & $\begin{array}{l}\text { 1.Objectively evaluate the process and results of students' task completion, point } \\
\text { out the shortcomings, praise the advantages, build students' self-confidence, and } \\
\text { let students have a clearer and deeper understanding of their own gains and losses; } \\
\text { 2.Summarize and expand the corresponding knowledge points and topics, enrich } \\
\text { students' knowledge accumulation. }\end{array}$ \\
\hline
\end{tabular}


4.2 Teaching design of activity view of English learning

\begin{tabular}{|c|c|}
\hline $\begin{array}{l}\text { Teaching } \\
\text { procedures }\end{array}$ & Activity design \\
\hline $\begin{array}{l}\text { Discourse-based } \\
\text { learning and } \\
\text { understanding } \\
\text { activities }\end{array}$ & $\begin{array}{l}\text { It includes activities of perception and attention, acquisition and } \\
\text { combing, generalization and integration. } \\
\text { 1.Create situations around the theme and activate the students' existing } \\
\text { knowledge and experience; } \\
\text { 2.Provide students with the necessary cultural background knowledge to } \\
\text { achieve text-based information input; } \\
\text { 3.Through summarizing and integrating information, establish the } \\
\text { correlation between information, and perceive meaning and the cultural value } \\
\text { orientation. }\end{array}$ \\
\hline $\begin{array}{l}\text { Practical activities } \\
\text { of deep discourse } \\
\text { application }\end{array}$ & $\begin{array}{l}\text { It mainly includes activities of description and interpretation, analysis } \\
\text { and judgment, internalization and application . } \\
\text { Guide students to carry out in-depth discourse communication activities } \\
\text { around the theme and the new knowledge structure formed, gradually realize } \\
\text { the internalization of language knowledge and cultural knowledge. }\end{array}$ \\
\hline $\begin{array}{c}\text { Translating and } \\
\text { innovating activities } \\
\text { beyond discourse }\end{array}$ & $\begin{array}{l}\text { It mainly includes reasoning and argumentation, criticism and } \\
\text { evaluation, imagination and creation activities beyond the text . } \\
\text { Guide students to reason and demonstrate the author's attitude behind } \\
\text { the text, explore its relationship with the theme meaning, deepen the } \\
\text { understanding of the theme meaning, and then promote the transformation of } \\
\text { ability to literacy. }\end{array}$ \\
\hline
\end{tabular}

\subsection{Design of activity view of English learning under TBLT}

The design of activity view of English learning under the TBLT not only embodies the essence of "task", that is, the four components of the task: purpose, context, process and product, but also matches the four elements with the three major types of English learning activity view to design our teaching content. As Zhang Qiuhui, Wang Qiang and Jiang Jingli ( 2016 ) believe, based on the task-based teaching method, setting up the task of learning understanding, applying practice and transferring innovation to promote the cultivation of students' core literacy can realize a huge leap from textbased information input to deep text first-order output and finally to higher-order output beyond text. 


\begin{tabular}{|c|c|c|}
\hline TBLT & & $\begin{array}{c}\text { English learning } \\
\text { activity view }\end{array}$ \\
\hline Pre-task & $\begin{array}{l}\text { 1.Define the goal of activity task to develop students' core } \\
\text { accomplishment of subject; } \\
\text { 2.Pre-class preparation: teachers read the textbook +students } \\
\text { preview; } \\
\text { 2.Lead-in: using the topic related to students' personal } \\
\text { experience and personal feelings to provide students with text } \\
\text { background information with pictures, questions, videos and } \\
\text { other information; } \\
\text { 4.Skimming: the general idea, plot and structure of the } \\
\text { article. }\end{array}$ & $\begin{array}{c}\text { Learning } \\
\text { comprehension } \\
\text { activities }\end{array}$ \\
\hline While-task & $\begin{array}{l}\text { 1.Scanning: understanding of the details of the article such } \\
\text { as character, story line, cultural information and rhetoric; } \\
\text { 2.Understand and analyze the style of the article and discuss } \\
\text { its linguistic and structural features; } \\
\text { 3.Group description or class sharing, exchange information } \\
\text { and promote their internalization of language and cultural } \\
\text { knowledge. }\end{array}$ & $\begin{array}{c}\text { Practical application } \\
\text { activities }\end{array}$ \\
\hline Post-task & $\begin{array}{l}\text { 1.Objectively evaluate the process and results of students' } \\
\text { task and give constructive opinions; } \\
\text { 2.Reason and demonstrate the author's attitude behind the } \\
\text { discourse, exploring its thematic significance; } \\
\text { 3.Promote students to think about the current situation in } \\
\text { their country based on the specific learning situation, the } \\
\text { appropriate depth excavation of the theme and the comparison } \\
\text { between China and foreign countries; } \\
\text { 4.Promote the cultivation of students' thinking quality and } \\
\text { cultural awareness through independent, cooperative learning } \\
\text { style and topic discussion. }\end{array}$ & $\begin{array}{c}\text { Migration of } \\
\text { innovative activities }\end{array}$ \\
\hline
\end{tabular}

4.4 Example analysis -- taking reading class in high school as an example

This article selects Oliver asks for more as the reading material in the seven module 3 of the foreign edition of high school English. This article is a piece of Oliver Twist written by the famous British novelist Charles Dickens and is a typical narrative.

\subsubsection{Preparation stage}

Teacher: (1) Studying the textbooks in depth and make clear the important and difficult points; (2) Establishing the overall objectives of the unit and developing hierarchical teaching objectives; (3) Designing and implementing interlocking and progressive teaching activities.

Students: pre-class preview: (1) The author's life story of Dickens; (2) Understand the main story plot to set up a story 
frame; (3) Eliminate the unfamiliar words, syntactic and grammatical knowledge points.

4.4.2 Pre-task stage -- Perception and understanding

(1) Check the preview task, show Charles Dickens pictures and activate the information gap through questions: What did you know about Charles Dickens? What do you want to know about him? (2) Broadcast a video related to topic to provide students with text background information; (3) Give students tasks to generalize and integrate. For example, what's the main idea of this passage? How is the text organized?

4.4.3 While-task stage -- applied practice activities

(1) Scanning: find out the character of the protagonist Oliver and fill in the blanks about what characters Oliver has? (2) The panel describes the clues based on the questions about why he was hanged? to exchange information, and expand their knowledge reserves; (3) It is difficult for students to analyze and judge this article's style and find out its language characteristics. The teacher should give students corresponding tips to understand the characteristics of English classical literature, and Chinese classical literature of the same period, and understand their contribution to world culture.

4.4.4 Post-task stage -- migration of innovative activities

(1) First of all, dialogue with the author, explore the meaning of the text and develop logical and critical thinking:

What's writer's opinion on Oliver and his life?

In the writer's opinion, what did Oliver really ask for?

What did the writer intent to convey?

(2) Think what may "Oliver" symbolize in today's life? Display some pictures or videos of the actual situation in the country, and inspire students to think the word of "orphan" and emotional resonance of the real children;

(3) Inspire students to think how to deal with the problem of "orphan"? Let students focus on national policies and develop a sense of ownership.

4.4.5 Testing and evaluation

(1) Objectively evaluate the performance of the students' personal tasks and group cooperation; (2) Consolidate what you have learned. You must review the intake of discipline core literacy throughout the process; (3) Give homework -correct more information about the novel and make a brief book review; if you have a chance to help those "orphan", what would you do? Use the vocabulary, sentence patterns and grammatical knowledge points learned in this unit as much as possible.

\section{Design Principles and Considerations}

(1) Teachers need to improve their abilities and professional qualities (Liu Jingqiong, 2018). The task-based teaching method is different from the traditional indoctrination education method, which emphasizes the student as the main body, pays attention to exert the student's subjective initiative in the learning process, and the role of autonomous learning and cooperative learning in the task process. This requires teachers to organize classroom activities, grasp the rhythm and dynamic development of the classroom, and can flexibly solve the unexpected situation in the classroom. In the process of students completing their tasks, teachers should have foresight on the questions that students may ask and be ready to answer questions at any time (Liu Yanli, 2016). Also, activity view of English learning involves a chain of activities in cycle, namely, the last activity can become the cushion of the next activity, and the next activity is the deepening and expansion of the last activity. It requires the teacher's ability to study and design, so the teacher's role is not only as a controller, organizer, facilitator, participant and resource provider, but also as a helper, researcher and lifelong learner in the new era.

(2) Task activities should be designed in accordance with the principles of easy-to-difficult, step-by-step and "self- 
fulfilling”. The design of task activities should grasp the principles of practicality and maneuverability. We all know that the development of human beings is sequential, and the cognitive ability of language will show different characteristics at different stages. Teachers should design appropriate tasks and activities according to the characteristics of the students in the stage. At the same time, the development of people is different, different students in language learning, strategies and other aspects of thinking and acceptance ability are more or less different, so teachers should use stratified tasks or homework based on the differences between students.

(3) The situation of task activities should be as real as possible, and close to the actual life of students. Task-based teaching method comes into being with the emergence of communicative approach, which is an important product of communicative approach. As Wang Qiang (2006) said, "the common denominator between communicative approach and task-based approach is that task language learning should be as close to real life as possible." Only the real context can activate students' existing knowledge or information to the greatest extent, arouse students' interest in understanding and exploring the topic, further understand the author's intention and the theme ideas expressed in the article and apply practice and transfer creation on the basis of perception and understanding.

(4) We should pay attention to the cultivation of harmonious relations between teachers and students during the whole task. We must give full play to the role of teachers, teachers can not only solve doubts traditionally, but also guide students. We often say that "it is better to teach a man to fish than to give him a fish." What we teach students is not only knowledge, but more importantly, teaching learning. Meanwhile, we should design group work and team work in the task link, so that students can strengthen their understanding of each other and cultivate the sense of cooperative team. And the harmonious relationship between teachers and students can easily arouse mutual emotional resonance when excavating the theme of the text.

(5) The integration of task-based teaching method and English learning activity view is flexible and diverse. Taskbased teaching method does not have a set of fixed models, as long as it conforms to the essence of "task", it is constantly adjusted with the development of the times. Also, the activities designed by the English learning activity view will be adjusted according to the specific learning situation, the type of class, the depth of the topic meaning excavation and the actual effect of the teaching activities. Therefore, there are some differences in the degree of integration between taskbased teaching method and English learning activity view. The design of any learning tasks is in line with the concept of learning activity advocated by the Curriculum Standard, as long as it attaches the importance to the overall development of students' literacy, the integrated learning and application of knowledge, skills and strategies in context, and the integration of language, thinking and culture.

\section{Conclusions}

To sum up, in high school English classroom teaching, teachers should skillfully implement task-based teaching method, meet the basic requirements of new curriculum reform and quality education, and improve students' comprehensive English use ability in an all-round way. Specifically, teachers should grasp the implementation steps of the specific task-based teaching method, and skillfully use a variety of teaching methods in practice, take advantage of strengths and circumvent weaknesses, and give full play to the classroom advantages of the task-based teaching method. At the same time, under the guidance of the concept of English learning activities, teachers should carry out all kinds of activities to develop students' core literacy in English subjects. Of course, the integration of task-based teaching methods and activity view of English Learning is very demanding for teachers and students themselves, which requires teachers to constantly improve their professional ability and cultural literacy, and to spend a lot of time preparing lessons. Teachers need to seriously consider the objects, levels and ways of each task design. Students need to have a certain language 
foundation and learning ability, like to explore and hold self-discipline and self-control to complete the task. In a word, we should integrate task-based teaching method and English learning activity view into teaching and learn from each other according to the actual situation.

\section{Conflicts of Interest}

The author declares no conflicts of interest regarding the publication of this paper.

\section{References}

[1] Ministry of Education of the People's Republic of China. (2003). General High School English Curriculum Standards: experiments. People' Education Press.

[2] Ministry of Education of the People's Republic of China. (2018). General High School English Curriculum Standards (2017 Edition). People's Education Press.

[3] Ellis R. (2009). Task-based Language Teaching: Sorting out the Misunderstandings. International Journal of Applied Linguistics, 19(3): 221-246.

[4] Yu L.J. (2016). The Application of Task-based Teaching in English Reading Teaching in Senior High School -Take the Human Education Edition Module 5 Unit 5 First Aid for Burns as an Example. Asia-Pacific Education (9): 49.

[5] Zhang Q.H. and Wang Q. (2016). Five Angles of Text Interpretation. Foreign Language Teaching in Schools (39): 16.

[6] Wang Q. (2006). English Teaching Course. Higher Education Press.

[7] Liu J.Q. (2018). On Senior English Classroom Teaching based on Task-based Teaching Method. English teacher, (18): 59-61. 